\title{
Institutions and the resilience of biobased production systems: the historical case of livestock intensification in the Netherlands
}

\author{
Catrien J. A. M. Termeer ${ }^{1}, \underline{\text { Peter H. Feindt }}{ }^{2}$, Timos Karpouzoglou $^{3}, \underline{\text { Krijn J. Poppe }}^{4}$, Gert Jan Hofstede $^{5,6}, \underline{\text { Koen Kramer }}^{7}, \underline{\text { Lan Ge }}^{8}$, \\ Erik Mathijs ${ }^{9}$ and Miranda P. M. Meuwissen ${ }^{10}$
}

\begin{abstract}
Disconnects between farming and urban systems are widely seen as impairing the resilience of biobased production systems (BBPSs). However, the institutional mechanisms that underlie these resilience problems are not well understood. In this explorative paper, which integrates elements from institutional and resilience theory, we develop a framework to analyze how institutionally shaped patterns of connects and disconnects affect the resilience of BBPs along the dimensions of robustness, adaptability, and transformability. This framework is applied to the historical case of pig livestock intensification in the Netherlands from 1870 to 2017. The case shows that institutions, successfully established in earlier periods, shape connects and disconnects in subsequent periods, thereby enabling and constraining resilience. A combination of perturbations, institutional layering, and shifts in ideational power is an important institutional mechanism for resilience. We conclude that building resilience requires a variety of reconnecting institutions and refraining from a focus on local reconnects or certification only.
\end{abstract}

Key Words: biobased production system; connects; institutions; livestock; resilience

\section{INTRODUCTION}

Biobased production systems (BBPSs) around the world are subject to unpredictable shocks as well as prolonged stress at multiple spatial and temporal scales, testing their resilience. We refer here to BBPSs as social-ecological systems that combine social organization, human technology, biological processes, and ecological systems and deliver services for the production of food, fiber, and fuel ( $\mathrm{Ge}$ et al. 2016). The sources of shocks and perturbations range from climatic change and animal diseases to volatile commodity prices, geopolitical conflicts, and societal protests, e.g., over animal welfare or the allocation of land and water (Steffen et al. 2007, Bues and Theesfeld 2012, Sage 2013, Zoomers et al. 2017, Vij et al. 2018). The loss of resilience can transform BBPSs into unhealthy social-ecological systems that can no longer deliver their ecosystem-based services (Lamine 2015, Ge et al. 2016).

Many factors contribute to the increase or decrease in BBPS resilience. Nowadays, various scholars emphasize that disconnects between farming and urban systems are an important cause of decreased BBPS resilience (Sundkvist et al. 2005, Qviström 2007, Zhang et al. 2007, Eakin et al. 2009, Cumming et al. 2014, Lamine 2015, McKinnon et al. 2019). In farming systems, the important roles are played by farmers, farmers' organizations and cooperatives, knowledge institutes, suppliers of resources, and food processing and distribution organizations. Urban systems include not only consumers and neighbors, but also political agents who can raise their voice and (de)legitimize farming methods or policy measures. Simple examples of disconnects include consumers lacking information on the various impacts of production systems and consumers' preferences not reaching farmers. Cumming et al. (2014) predicted that mutually reinforcing processes of technological change, population growth, and urbanization would lead to disconnects between farming and urban systems that would increasingly crowd out connects. These disconnects would disrupt information flows that safeguard services linked to food production, potentially leading to collapse in terms of ecological degradation, rural poverty, and even famine in some regions of the world (Cumming et al. 2014).

To address resilience problems that arise from disconnects, many scholars emphasize the need for new institutional arrangements to reconnect the manifold actors in farming and urban systems (Ostrom 1999, Cashore 2002, Termeer et al. 2013, Sonnino et al. 2014, Cretella and Buenger 2016). Sundkvist et al. (2005:233) state that, "When feedback loops are loose and less direct, there is a need to develop or strengthen institutions that can handle large geographical and temporal distances." The underlying argument is that connects and disconnects are mediated through institutions, defined as the rules that shape societal interactions (March and Olsen 1989). However, to evaluate and design alternative institutional arrangements, a more in-depth understanding is needed of how institutions influence resilience, by both enabling and constraining connects. More broadly, the institutional mechanisms that underlie the main resilience problems tend to be underemphasized (Biesbroek et al. 2017).

Against this background, this explorative paper seeks to address the question: How do institutions influence resilience in complex BBPSs through shaping connects and disconnects? It first presents a theoretical framework that defines the key concepts of resilience, institutions, and connects and conceptualizes the mutual interrelations. This framework is used to re-examine a rich and well-documented historical case: the intensification of the

${ }^{1}$ Public Administration and Policy Group, Wageningen University and Research, The Netherlands, ${ }^{2}$ Albrecht Daniel Thaer Institute for Agricultural and Horticultural Sciences, Humboldt University at Berlin, Germany, ${ }^{3}$ Division of History of Science, Technology and Environment, KTH Royal Institute of Technology, Stockholm, Sweden, ${ }^{4}$ Wageningen Economic Research, The Netherlands, ${ }^{5}$ Information Technology Group, Social Sciences, Wageningen University and Research, The Netherlands, ${ }^{6}$ UARM, North-West University, South Africa, ${ }^{7}$ Wageningen University and Research, Wageningen University, The Netherlands, ${ }^{8}$ Wageningen Economic Research, Wageningen University and Research, The Netherlands, ${ }^{9} \mathrm{Department}$ of Earth and Environmental Sciences, KU Leuven, Belgium, ${ }^{10}$ Business Economics, Wageningen University and Research, The Netherlands 
pig livestock sector in southern Netherlands from the 19th century to the present day. Such a historical analysis is most suited to elucidating institutional mechanisms. The paper concludes with a discussion of the patterns identified in the case study and a more general conclusion about the lessons learned and their consequences for ideas about reconnecting institutions.

\section{THEORETICAL FRAMEWORK}

The concept of resilience was originally coined by ecologists to analyze nonlinearities, critical thresholds, and irreversibility in ecological systems (Anderies et al. 2013). Nowadays, resilience has evolved into a powerful concept used in many disciplinary fields. As Biesbroek et al. (2017) have argued, caution is required when the concept of resilience is being applied to analyze broader societal or social-ecological systems rather than merely ecosystems. The structural complexity of ecological and social systems can be analyzed with similar terms, but the feedback processes are incomparable because of agency, e.g., the capacity of human beings to behave strategically, to include and exclude, to imagine, and to enhance collective action (Davidson 2010). The concept of resilience can be meaningfully applied to societal systems only if it deliberately includes and elaborates on human agency (Biesbroek et al. 2017) and if it provides normative clarification, because in social systems resilience is not necessarily the preferred response of all actors (Davidson 2010). Because institutions guide the behaviors of actors in societal systems, they thus also influence the resilience of these systems. In this context, we present a framework to analyze dynamic relations between institutions, connects/disconnects, and resilience. It is important to note that we do not analyze the resilience of institutions themselves but how they influence BBPS resilience through shaping connects and reconnects.

\section{Resilience of biobased production systems}

In general, resilience is understood as the capacity of a system to respond to perturbations while continuing to perform its basic functions. A resilience analysis always starts by addressing the question of "resilience of what to what": what is the system and what are the perturbations (Carpenter et al. 2001)? We analyze BBPSs, but it is crucial to identify the system boundaries of each case in more detail. Our case, for example, focuses on a specific farming system (pig husbandry) in a specific region (southern Netherlands). It includes trade-offs between this system and other economic sectors in this region (industries in cities) and other parts of the world (fodder production in Brazil). Perturbations, consisting of either strong shocks or persistent stress, can push a system toward a tipping point where it can no longer maintain its previous state (Holling and Gunderson 2002, Reyers et al. 2018). In the context of BBPSs, perturbations can emerge from internal or external economic, social, or physical processes. If the BBPS is not able to respond to the perturbations, it may lose its ability to deliver certain ecosystem-based services, including food, fodder, or fiber production, clean water, climate regulation, biodiversity, pest regulation, or attractive landscapes (Cumming et al. 2014, Ge et al. 2016).

\section{Robustness, adaptability, and transformability}

Because resilience has become a broad cluster of concepts, we follow various authors (Davidson 2010, Folke et al. 2010, Anderies et al. 2013, Meuwissen et al. 2019) who have distinguished three subcapacities of resilience: robustness, adaptability, and transformability. These dimensions differ in terms of timescale and depth of change. Robustness or persistence is the capacity to maintain the same functions and desired levels of outputs despite the occurrence of perturbations; it is the ability to bounce back or return to a previous equilibrium (Urruty et al. 2016, Reyers et al. 2018). The focus is on continuation of the status quo with marginal adjustments. Adaptability is the capacity to respond to shocks and stresses by adjusting internal processes. It allows for new developments along current trajectories and without changing the dominant logic of operation (Folke et al. 2010). Transformability is the capacity to create a fundamentally new system to capture novel opportunities or respond to either severe anticipated/unanticipated shocks or enduring stress that make the earlier system untenable (Walker et al. 2004, Olsson et al. 2006, Westley et al. 2011, Termeer et al. 2017). What emanates from the process of transformation might be an entirely different system. This implies that authors who relate resilience to maintaining also a degree of identity (e.g., Gupta et al. 2010) might qualify transformation as not resilient.

\section{Institutions}

Institutions are rules that shape patterns of political, economic, and social interactions, without determining them (March and Olsen 1989, North 1991, Williamson 2000). The rules can be formal governmental policies and informal social patterns of engagement; they can be visible or latent; and they can generate productive and innovative as well as destructive and perverse outcomes (Geels 2004, Arts 2006, Ostrom 2009). If we refer to a ministry, a cooperative, or an environmental NGO, it refers to actors embedded in institutions.

Institutions are constructed, validated, and adjusted in interactions between actors operating at different scales of time and place. Their functioning is in manifold ways linked to the exercise of power, defined as the ability to have an effect upon the context that defines the range of societal actors' possibilities (Hay 2002). The structural power dimension of institutions refers to the (unequal) social distribution of material and immaterial resources (Bachrach and Baratz 1962, Thelen 1999). Institutions also embody specific ideas and privilege, and support or oppress specific ideas. This is referred to as ideational power, which affects people's beliefs and values (Carstensen and Schmidt 2016). Examples include social pressure in a local community, the influence of the Catholic Church, or the promotion of technologies.

Institutions designed and negotiated at one point in time affect subsequent choices, creating institutional trajectories or path dependencies, because every generation typically inherits institutions that reflect previous actors' preferences, circumstances, and power configurations (Thelen 1999, Pierson 2004, Duit et al. 2015). Institutions change slowly and incrementally consequent to lock-ins (Pierson 2004). Institutionalized rules often reproduce or reinforce structural or ideational power (Lukes 1974) or can become a source of power in themselves. Therefore, existing power structures often constrain institutional change. Despite this conservativism, institutions can develop as a result of changes in environmental conditions, shifts in power balances, or unanticipated effects, in particular at critical junctures (Pierson 2004). If a BBPS is not sufficiently resilient to perturbations, the loss of key functions might trigger a critical juncture that enhances 
adjustments, and hence might function as a window of opportunity for institutional change (Westley et al. 2011, Duit et al. 2015). However, such change requires awareness of the expected loss of key functions and hence effective feedback patterns.

\section{Connects and disconnects}

In a BBPS, as in all complex systems, all actors continuously make choices (including doing nothing) based on input obtained from the social and ecological systems with which they are interacting. These feedback loops are enabled by connects between different parts of the system. In the case of disconnects, actors are separated in place or time from the direct or indirect consequences of their own activities, and feedback loops are consequently interrupted. Local food systems, for example, have tight feedback loops in which consumption and production activities, consumers, and producers, or economic, environmental, and social effects are closely connected (Sundkvist et al. 2005).

Because most BBPSs transcend local boundaries, more direct feedback loops need to be replaced by other institutionalized feedback mechanisms to avoid disconnects. Sundkvist et al. (2005:225), for example, emphasize "the need to establish or strengthen institutions for managing feedback information between the various parts of the system," and Anderies et al. (2013) refer to rules that translate information about a system into action that feeds back into the system. Needless to say, that information is not directly related to behavioral change; it is only one of the drivers in a complex process (e.g., Vatn 2005). In the literature, most emphasis is placed on managing information, but, in our framework, we include connects that are organized through material and financial flows (Hull et al. 2015). Information flows in BBPSs involve transmitting and updating knowledge about products, production systems, externalities, price signals, behavior, and preferences (Ge and Brewster 2016). Financial flows consist of payments, credit terms, taxes, and subsidies (Ge and Brewster 2016). Material flows include any type of matter, resulting from biological, chemical, and physical processes (Hull et al. 2015). Institutions influence flows in many ways, not least through institutionalized rules on access to material, financial, and informational resources (for example, Moulier-Boutang 2011).

To analyze connects and disconnects, we therefore need to look in particular at institutionalized alignments or misalignments between these three different types of flows. For example, if commercial and trade laws facilitate material and financial flows but intendedly or unintendedly restrict information flows about their effect on common pool resources, negative external effects of the commercial transactions will be invisible to many market participants, thereby disconnecting the trading parties from those affected by deteriorating common pool resources (Cosens et al. 2014). Disconnects are further exacerbated if the rules on resource use are not well aligned with local needs, if those affected by the use of a resource have little or no influence on these rules, if material and financial flows are not well monitored, if transaction costs to remedy disconnects are high, and if local rules are not well aligned with higher level institutions (Ostrom 1999). Consequently, connects and disconnects are both manifestations and sources of structural and ideational power.

An institutional analysis is helpful not only to analyze new reconnects, but also to understand which historical institutions caused them. Sundkvist et al. (2005) identified four drivers for increased disconnects between farming and urban systems: intensification, resulting in separating food production from local ecosystems; specialization, leading to separating plant from animal production; distancing, food traveling longer distances; and homogenization, resulting in the loss of local knowledge. Although these developments result from individual decisions of farmers and other business actors, they are predominantly guided by institutions that promote the paradigms of intensification, specialization, and homogenization through structural and ideational power.

\section{CASE STUDY AND METHODS}

We use a well-documented historical case study of pig livestock intensification in southern Netherlands to explore how institutions influence connects and disconnects in complex BBPSs. After benefitting from the Dutch Golden Age in the 16th and 17th centuries, agriculture in southern Netherlands experienced a long period of stagnation in the 18th and 19th centuries. Manure was the limiting factor for subsistence farming on poor heathlands and sandy soils. From the late 19th century, however, incentivized by growing demand from cities in England and the Ruhr area in Germany, southern Dutch farmers greatly expanded livestock farming (mainly pigs) by using imported feed that made them less dependent on their own poor soils. Pig farming evolved into a gigantic intensive livestock industry with even more pigs than inhabitants at its zenith in the 1990s. Before 1900 , most farmers had one pig for household consumption, whereas nowadays the average number of pigs per farm is 2400 (Van der Heijden and Cramer 2017).

During this period, the pig livestock sector in southern Netherlands faced many internal and external perturbations and went through different stages of development, including major institutional change. From a comprehensive literature analysis, we have distinguished five developmental stages that each include a sequence of specific economic, social, and ecological perturbations (see Table 1). Although the period 1920-1945 includes many perturbations, commonalities in institutional and response patterns prevail, so that we decided to present it as one stage.

Table 1. Developmental stages of the livestock sector in southern Netherlands.

\begin{tabular}{lll}
\hline \hline Stage & Period & Main perturbations \\
\hline 1 & $1870-1920$ & $\begin{array}{l}\text { Agricultural crisis and WWI } \\
2\end{array}$ \\
$1920-1945$ & $\begin{array}{l}\text { Economic depression in the 1930s, World War II } \\
\text { and German occupation (1940-1945) }\end{array}$ \\
3 & $1945-1970$ & $\begin{array}{l}\text { General recovery after World War II } \\
\text { The manure problem and outbreak of swine fever } \\
(1998)\end{array}$ \\
5 & $1970-2000$ & $\begin{array}{l}\text { Accumulation of human health risks linked to } \\
\text { intensive livestock systems }\end{array}$ \\
\hline
\end{tabular}

Despite pig livestock intensification in southern Netherlands being a well-documented case, it has not been analyzed through the conceptual lens of resilience. The data have been derived from all published literature on the subject, e.g., all reports, papers, and books that provide a broad historical analysis of the pig husbandry from a social science perspective (key references: 
Termeer 1993, Bekke et al. 1994, Frouws 1994, Van Zanden 1994, Wiskerke et al. 2003, Bieleman 2010, Bijman et al. 2012, van Lieshout et al. 2013, Bijman 2018). This was complemented by the knowledge and experience of the authors in this field.

For each stage, we use our theoretical framework to explain how the BBPS, the regional pig livestock sector, responded to the main perturbations; how these perturbations and responses affected institutions, connects, and disconnects; and the consequences for BBPS resilience along the dimensions of robustness, adaptability, and transformability. From a BBPS perspective, the level of analysis is the whole system and its overall ability to deliver public services and maintain common pool resources, not the resilience of individual farms.

An important limitation of this study is the fragmentation of sources. Although the various stages of the case are well documented, none of the sources covers the entire period, and none of them has presented and interpreted the data from a resilience perspective. Furthermore, we present only a very brief account of a very complex and long period. The main aim of the case study is to show the usefulness of the theoretical framework by analyzing some overall patterns, providing orientation for future comparative and more in-depth studies.

\section{RESULTS: A RESILIENCE AND INSTITUTIONAL ANALYSIS OF PIG LIVESTOCK INTENSIFICATION IN SOUTHERN NETHERLANDS, 1870-2017}

\section{Stage 1 (1870-1920): transformability in response to agricultural crisis}

\section{Perturbations}

Between 1870 and 1880, Europe experienced several major agricultural crises. The Midwest of the USA had been colonized in the 19th century, and new railroads and steamboats brought grains to Europe. Grain prices decreased drastically, and many Western European farmers shifted to livestock production (van Zanden 1994). Germany and the UK became major export markets demanding light pigs of $40-65 \mathrm{~kg}$, the so-called London piglets. This market was attractive for small farms because less working capital and land was required, and many more or less landless persons were able to start a small farm (Bieleman 2010).

\section{Institutions}

Early initiatives to improve the organization of the agricultural sector date from the mid-19th century. Agricultural societies were founded at the provincial level by the powerful bourgeois elite and wealthy farmers (van Zanden 1994). In southern Netherlands, the Catholic farmers' organization became the most influential. This movement was strongly directed by the Catholic Church, which lent legitimation to the new institutions and their ideational power (Bijman 2018). As a response to the agricultural crisis, the farmers' organization initiated the foundation of cooperatives through which small farmers collectively purchased and traded, thereby increasing their structural power (Bijman 2018). The cooperatives used the window of opportunity caused by the crisis and organized a pig-feed supply transport infrastructure with the nearby Rotterdam harbor (Bieleman 2010). After 1880, the Dutch government also began to facilitate agricultural production by providing education, extension, and research (van Zanden 1994), thereby executing strong ideational power by promoting pigs as well suited for small farms and economically very efficient because they could recycle many sources of waste. Furthermore, the Netherlands' adoption of policies to prevent the overexploitation of heathland limited opportunities to increase arable land and thus indirectly promoted pig husbandry (Bieleman 2010).

\section{Connects and disconnects}

Cooperatives enhanced financial and material flows between farmers and urban systems. These institutions were efficient in aggregating supplies from remote rural regions in southern Netherlands to far-away markets in urban areas in Germany and the UK, and in bargaining feed for livestock (Bijman et al. 2012). Material flows were balanced with ecosystem services. The increasing volumes of manure were used as fertilizer for the poor sandy soils. The use of waste for fodder connected pig farmers with urban waste processors. The cooperatives mediated information flows on prices and demand, but not on social and cultural developments. Urban artists, living in dirty and poor cities, played an important role in such information flows by enhancing a process of romanticizing the countryside, thereby creating imagined connects but informational disconnects (Bieleman 2010).

\section{Resilience}

The depressed agricultural prices in the 1880 s were a major perturbation that could have brought misery and collapse with overexploitation of heathlands, but effective management rules for the commons prevented this. The newly formed farmer cooperatives became crucial institutional arrangements for reconnecting farmers with urban centers and coping with overseas market-related perturbations. The cooperatives, built upon earlier organizational efforts by the bourgeoisie and wealthy farmers, were based on rules providing membership and access to resources. Investment in research and extension created a new dominant farming paradigm with ideational power and further incentivized the reorganization of the livestock sector. Altogether, these newly formed institutions enhanced the transformative capacity of the sector, leading to an increase in livestock and farm income without breaking the ecological feedback loops.

\section{Stage 2 (1920-1945): adaptability in response to economic depression and World War II}

\section{Perturbations}

This a dynamic period, including times of wealth and optimism, deep economic crisis, and a war. After World War I, farming was hit by new perturbations as trade resumed and many men entered farming because of the lack of employment outside agriculture, resulting in (land) fragmentation (Bieleman 2010). The situation deteriorated with the economic depression after the 1929 Wall Street crash and the abandonment of the gold standard by the UK in 1931. Farm income fell to very low levels and alternative income opportunities disappeared (Bijman et al. 2012). The situation was further exacerbated during World War II, with increasing food shortages across Europe and the German occupation of the Netherlands.

\section{Institutions}

The cooperatives and farmers' organizations, established in the previous period, were able to counteract some of the negative effects of fragmented and unstable international markets by using structural and ideational power. They established an institute for agricultural economics to show policy makers and the general public how bad the situation was and successfully advocated a 
specific agency to support small farmers (Bijman et al. 2012). Their powerful lobby facilitated a strong government response with the introduction of a crisis pig law, which reduced supply and guaranteed minimum prices (Bijman 2018). This shift from a noninterventionist economic policy to strict regulation continued during the war years (Bijman 2018). Besides these agricultural policies, governmental research and extension agencies continued to stimulate technological innovation, exercising strong ideational power (Bieleman 2010).

\section{Connects and disconnects}

The economic crisis and WWII disconnected farmers from many material and financial flows that had enabled their economic revival in the previous period, in particular feed imports and export markets. This resulted in poverty, the slaughtering of animals, and a breakdown in production, to the extent that strong government interventions were supported by all political parties (Bijman et al. 2012). The intervention policies disconnected supply and demand decisions from information flows and connected them to authoritative decisions by the government. The food shortages during WWII and the German occupation further reinforced the connection between government information about nutritional needs and authoritative decisions about resource use and food distribution. Simultaneously, food shortages somewhat reconnected broken feedback loops, because citizens increasingly visited farms in search of food (Bieleman 2010). This created an acute awareness of interdependencies between urban and rural areas that lasted for decades.

\section{Resilience}

Overlapping political, economic, and social crises could have led to the collapse of the pig livestock sector. However, the livestock sector in southern Netherlands showed remarkable resilience and high adaptive capacity in the face of serious perturbations. Building on established institutions of farmers' cooperatives, research institutes, and extension, and supported by governmental interventions, the system replaced unviable connects (depressed markets, interrupted international trade) with new ones (managed markets, bartering prices) and was able to maintain food production services, albeit at a lower level than before. During this period, nothing was reported about environmental or ecological trade-offs.

\section{Stage 3 (1945-1970): transformability in response to recovery challenges after WWII}

\section{Perturbation}

World War II left the Netherlands with significant war damages. Farmers faced the choice of migration to the industrializing cities, emigration, or rebuilding their farms with support from the U.S. Marshall Plan. With the industrialization and rebuilding of Western Europe, farm labor became scarce, resulting in increasing labor costs (Bieleman 2010).

\section{Institutions}

The strong presence of the state from the previous stage continued. The Ministry of Agriculture, Fisheries, and Food Supply issued an extensive agricultural policy to feed the country and to create an income source through exports (van Lieshout et al. 2013). In 1958, agricultural market and price policy was transferred to the European Common Agricultural Policy (CAP). Effective lobbying by several supply-chain actors led to the exemption of citrus pulp, tapioca, and soya, which were used as feedstuffs, from CAP import levies (Bijman et al. 2012). The sector was also strongly supported by governmental services for education, extension, and research that promoted specialized intensive livestock farms and disincentivized mixed farms (Bieleman 2010). The ministry collaborated intensively with the farmers' organizations and cooperatives, sharing a modernization paradigm of mechanization, specialization, and larger scale farming (Frouws 1994, van Lieshout et al. 2013). This institutional support (structural power) and the shared modernization paradigm (ideational power) provided a strong basis for revitalizing and transforming the pig livestock sector (Frouws 1994).

\section{Connects and disconnects}

The food shortages during WWII had reminded urban dwellers of the importance of agriculture and the crucial position of farmers. This gave the ministry the opportunity to extend the crisis-based agricultural policy as a general agricultural support policy with the aim of "no more hunger." It later also legitimized the upscaling of these policies to European agricultural policy. These policies connected farmers with important material flows, i.e., animal feed, and financial flows, i.e., state and EC subsidies, that enabled their economic revival, as well as increasing market incomes. Specialization and economies of scale were increasingly based on feed imports, and this facilitated a "landless" type of farming with high added value (Bijman et al. 2012). However, the specialization and intensification also contributed to growing disconnects, e.g., between overseas fodder production and environmental effects in southern Netherlands or overexploitation problems in feed-producing (tapioca and soy) countries overseas. The more local environmental issues were not yet a disconnect: the bad smell from pig farms was framed as "healthy rural air," an exercise of ideational power that reinforced a positive identity frame for farmers. Effects on local water quality and nature areas had not yet materialized, because it takes time for soils to become saturated with phosphate or for the effects of air pollution to accumulate. Early warnings in scientific reports about, for example, the growing manure surplus were dismissed (Termeer 1993, Frouws 1994).

\section{Resilience}

A combination of powerful, long-standing institutions and new forms of organized institutional support enabled a rapid transformation process that went beyond mere recovery and significantly altered the social, economic, and ecological logic of operation of the Dutch pig production system. This transformation was predominantly framed as a great success. Ecological concerns slowly entered the public domain but did not receive much media attention. By the end of this period, the main institutions used their structural and ideational power to disregard early signals about overproduction and adverse ecological effects that did not fit their agricultural modernization paradigm.

\section{Stage 4 (1970-2000): robustness in response to contested "license to produce"}

\section{Perturbations}

The intensification of pig livestock production led to growing societal and political concerns about the negative consequences of agricultural modernization, such as overproduction, environmental pollution, animal diseases, and animal welfare 
issues (Wiskerke et al. 2003). From the late 1970s, the CAP system of market support increasingly led to overproduction and increasing costs for market intervention. Reports indicated that the excessive use of manure saturated soils with phosphate and led to air and water pollution with nitrates and ammonia (Termeer 1993). Animal welfare entered the agenda with a critical assessment of the dense housing systems for pigs and poultry. In 1997-1998, a massive outbreak of swine fever hit the Netherlands. The many societal concerns increasingly delegitimized intensive pig husbandry, questioning its "license to produce" (Breeman 2006).

\section{Institutions}

The strong institutional collaboration from the previous period developed into a closed neo-corporatist policy community dominated by the Dutch Ministry of Agriculture, farmers' organizations, and agricultural specialists in parliament (Bekke et al. 1994, Frouws 1994). This community was united by the modernization paradigm and exercised strong ideational power, marginalizing alternative ideas (Wiskerke et al. 2003). The previously powerful cooperatives and farmers' organizations displayed a history of failure to self-regulate manure problems (Termeer 1993). Weakened manure regulation was introduced piecemeal between the early 1980s and the millennium, ushering in a complex, often ineffective, accumulation of EU and national policies. To combat swine fever, 12 million pigs were culled, some in eradication efforts but most for associated welfare reasons, at a total cost of $€ 2.3$ billion (Meuwissen et al. 1999). In response, national legislation was introduced to control and limit the growth of the pig production sector. Under financial pressure, the Ministry of Agriculture privatized its extension and research service in 1998 (Bijman et al. 2012). What farmers called innovative pig livestock farming systems was publicly denounced as "industrial farming," indicating a shift of ideational power from industry to public interest groups (Termeer 1993). The hegemony of the agricultural modernization paradigm vanished, and fundamental public controversies about the pig livestock sector emerged.

\section{Connects and disconnects}

The closed agricultural policy community and sector institutions contributed to disconnects between farming and urban systems. Whereas previously nonagricultural groups were not interested in agricultural policies, during this period they were deliberately excluded (Termeer and Werkman 2011). Attempts to hide negative trade-offs and thus disconnect material and information flows became counterproductive. Environmental and welfare NGOs stepped into this void and organized information flows about the effects of pig husbandry systems on environmental pollution and animal well-being. The swine fever outbreak and the accompanying media attention unintentionally resulted in a radical disclosure of information. Swine fever opened the eyes of many urban dwellers and created a broad public awareness of the realities inside pig sties. Sanitary measures to prevent bovine spongiform encephalopathy (BSE) limited the use of animalorigin waste for pig fodder, and feed sources shifted radically from industrial waste products to tapioca and soy. This exacerbated the disconnects between international material and information flows, resulting in blocked feedback loops between deforestation (in Latin America and Thailand) and environmental pollution and animal well-being (in the Netherlands).

\section{Resilience}

The manure problem, the problematization of animal welfare in the pig livestock industry, and the swine fever outbreaks strongly challenged the authority of pre-existing institutions, in particular their ideational power. However, despite the growing external critique, the sector remained economically robust, enjoyed continuing institutional support, and maintained enough structural power to marginalize or outmaneuver critics. Despite some internal attempts to reorganize the production system, the focus was on persistence and robustness, although for an increasing number of people it had become clear that the system was unsustainable. The increased demand for tapioca and soy contributed to the gradual collapse of virgin forests overseas, with negative environmental and social impacts. Finally, the immense fallout of the swine fever crisis indicated a systemic failure to deal with new forms of perturbations. Overall, the system actors used their ideational and structural power to relocate resilience issues to other places and into the future, exploiting informational disconnects and favoring robustness over transformability.

\section{Stage 5 (2000-2017): seeds of transformative change in response to an accumulation of risks}

\section{Perturbations}

The more restrictive policies for the pig industry issued in the previous period induced growth inter alia in the goat sector. However, in 2007, an outbreak of Q-fever, a zoonosis originating in goats, caused over 75 human deaths in southern Netherlands and also affected inhabitants in metropolitan areas. The Q-fever crisis brought into the spotlight other livestock-related health problems such as the MRSA bacterium, antimicrobial resistance, other zoonosis outbreaks, fine particles, and increased risks of pneumonia (Health Council 2012). Further restrictive regulations, including on animal health and manure, reduced the sector's profitability, resulting in fewer farms with more livestock, quickly labelled as "mega-stables" that became highly controversial (van Lieshout et al. 2013). Many pig farmers quit during this period. New challenges entered the agenda such as adaptation to climate change, $\mathrm{CO}_{2}$ reduction, and biodiversity loss, amplifying overlapping risks of human health, economic viability, and ecological degradation.

\section{Institutions}

In 2000, the Ministry of Agriculture tried to open up the closed policy community, announcing that the relation between the ministry and the agricultural sector had changed and allocating an important role to consumers, citizens, and society (van Lieshout et al. 2013). However, it responded only slowly to the Q-fever incident, indicating that ideational power still swayed incumbents to protect the industry's vested interests. The general public perceived the response as too little too late, and as only increasing the distrust in agricultural institutions (Termeer et al. 2016). The bad smell was no longer perceived as healthy rural air but as a health hazard, indicating a shift in ideational power. Citizens organized to ban intensive livestock production from their village or province. After intensive media coverage and political debates, local governments (municipalities and provinces) issued restrictive measures against further increases in livestock. Decades of environmental and societal critiques had undermined the ideational and structural power of agriculturalinterest organizations in favor of environmental, animal welfare, and health groups. 


\section{Connects and disconnects}

Paradoxically, the concerns over health and animal welfare contributed to reconnecting information flows, i.e., sharing information about health risks, between farmers and urban dwellers, a process that became particularly tangible at the local level (Termeer et al. 2016). The farming sector now had to face its implications for ecology, animal welfare, and public health. Not only urban dwellers who had moved to the countryside criticized their neighboring farms, but also traditional inhabitants of rural areas. Later, multinational corporations based in the province entered the debate because they depend on an attractive countryside for housing to attract talented employees. The province initiated compulsory dialogues between farmers and their neighbors to restore trust as a condition for building permits; this could be described as a province-enforced grassroots reconnect. Innovative arrangements emerged that deliberately aimed to reconnect cities with food and agriculture, for example, Agri Meets Design, television food chefs, youth food movement, city farming projects, or more environmentally or animal-welfarefriendly farmers marketing their meat under special labels. Even supermarkets now require higher levels of animal welfare and environmental standards from their farm-sector suppliers. All these initiatives enhanced information flows between cities and the countryside and shifted ideational power toward new concerns beyond growth and intensification. However, most farmers perceived operational growth as the only way to meet the demands of retailers, export markets, and banks, indicating a financial disconnect that moved economic power away from farmers. Having to pay off long-term investments, farmers experienced lock-ins and the paradox that citizens disapproved their production methods but were not willing to pay more for meat with higher environmental and animal welfare characteristics, so that financial flows were not well aligned with informational flows (Fresco and Poppe 2016).

\section{Resilience}

During this period, disconnects that were institutionalized in earlier periods created perturbations that tested the resilience of the pig sector in southern Netherlands: animal well-being, animal diseases, manure problems, and Amazonian deforestation were material disconnects that could no longer be hidden behind informational disconnects. Re-established informational connects undermined the ideational power of the closed agricultural policy community and its modernization paradigm, ushering in incremental institutional change through environmental, health, and animal welfare regulation. Even maintaining the status quo required significant adaptation. Many farmers, lacking both robustness and adaptability, quit. For those who stayed, contradictory resilience strategies have emerged. On the one hand, powerful market forces and agricultural lobbies aim to maintain robustness by mobilizing buffer resources and externalizing social and environmental costs. On the other hand, new actors within and outside the sector create manifold transformative innovations in reconnected niches in regions, value chains, or cities. However, it is difficult to upscale the seeds of transformative change because of lock-ins and path dependencies caused by the inertia of structural and ideational power and the institutional heritage of previous historical periods.

\section{DISCUSSION}

In the case study, we have used our framework to analyze how institutionally shaped patterns of connects and disconnects affected the resilience of the pig sector in southern Netherlands and which types of resilience were enabled and constrained over time. Below, we discuss the main patterns and mechanisms identified.

All periods show the mechanism of perturbations followed by institutional upheaval, a pattern that is also described by Newman (2000). In the earlier periods, the main sources of perturbations were social, political, and economic disasters, whereas in the postWWII era environmental and human health risks became more prominent. The case shows that sudden shocks, such as a war, a sudden market disruption, a stock market crash, or a disease outbreak had greater effects than what Rosenthal et al. (1989) referred to as creeping crises, such as environmental pollution, climate change, or increasing societal concerns about animal welfare. Creeping crises imply a temporal delay in feedback, cause fewer visible stresses, and are more likely to produce contested evidence, which all result in postponed responses.

The institutions that developed in response to perturbations enhanced the tightening of some connects or feedback loops while loosening or even interrupting others. Connects and disconnects between farming and urban systems exist simultaneously, but there is a tendency for an increasing number of disconnects to crowd out connects, what fits the conclusions of Cumming et al. (2014). A related pattern is the tendency for institutional changes to result in trade-offs rather than synergies between material, financial, and information flows. Cooperative formation in the first stage, for example, helped to mediate material and financial connections between farmers and city consumers, but it also resulted in romanticized images (artists' paintings) of farming consequent to broken direct interactions and thus broken information flows between farmers and urban dwellers.

Another mechanism is the globalization of commodity markets resulting in new connects and disconnects between production and consumption areas. The agricultural policy framework increasingly reinforced this pattern by enabling financial and material flows between Dutch farmers and overseas sources of feedstuff, but it simultaneously restricted information flows about their effects on deforestation and manure surplus problems, thereby disconnecting the benefitting parties from those facing the detrimental effects. Initially, this informational disconnect was unintended, but, when these problems were high on the political agenda, it became a deliberate strategy because benefitting parties had an interest in hiding this information. Connects and disconnects also emerged as delayed and unintended effects of institutional reforms. For example, the policies to combat swine fever by culling millions of pigs unintendedly opened the eyes of urban dwellers and thus reconnected information flows between the farm sector and citizens; this in turn triggered new policies to restructure the pig sector. Regarding all flows, changes from connects to disconnects or vice versa can even constitute new perturbations.

The patterns of connects and disconnects affect differently the main resilience dimensions of robustness, adaptability, and transformability, and include various trade-offs. The specific quality of the connects is more important than the number of 
connects. Material and financial connects enhance adaptability by providing access to resources as well as undermining robustness by exposing a system to superior competitors. Informational disconnects about negative environmental effects appear to strengthen robustness (and thus focus on the short term) but undermine adaptability and transformability (which is more related to the long term). New informational reconnects may form breeding grounds for transformability but risk financial disconnects through investor and customer responses, thereby undermining robustness. The effects of the same institutions on resilience dimensions also show dynamic effects over time. The cooperatives installed in the first stage were very important in shaping connections that enhanced transformability. In the second stage, these cooperatives played an important role in preventing collapse during WWII. Subsequently, they formed an important institutional breeding ground for another transformation period in the context of the post-WWII recovery. However, in the fourth stage, these previously successful institutions tried to preserve a privileged status quo by establishing disconnects that almost resulted in a collapse. That this collapse did not happen is the result of another important pattern, that is, that each period displayed a distinct mixture of all three types of resilience capabilities. In the fifth period for example, we observed not only signs that indicate collapse (deforestation, Q-fever), but also signals of robustness (production levels are maintained and many farms still continue), adaptability (mega-stables), and transformability (urban agriculture).

Another pattern is the increasing institutional complexity over time. The need for suitable feedback loops and thus resilience is an important driver of institutional complexity. The layering mechanism, as described by Thelen (1999) provides another explanation, meaning that old institutions are not replaced by new ones, but that new elements such as actors, rules, or policies are attached to existing institutions and so gradually change their status, structures, and outcomes. As the legacy of previous interactions and historically entrenched power relations, new agricultural institutions were layered on top of old institutions, a finding similar to Feindt and Flynn (2009). Part of this complexity is the emergence of parallel institutions or institutional redundancy. The WWII period, for example, showed the simultaneous emergence of government-led food production and distribution systems and local self-supporting farming systems that contributed to high levels of adaptability during this perturbation-filled period. This institutional complexity makes it hard to distinguish connecting and disconnecting mechanisms, as they may coexist and are simultaneously in a constant battle for prevalence. However, our case also supports the ideas of Ostrom (2008) and Folke et al. (2010), who emphasize the importance of institutional variety and redundancy as key prerequisites for resilience.

Finally, and in line with earlier work on the importance of agricultural policy paradigms (Daugbjerg and Feindt 2017, Feindt 2018), our case study identifies ideational power as an important factor in explaining institutional change and inertia. Ideational power reinforced path dependencies centered around disconnects while limiting space for the creation of new connects. In our case study, crucial junctures of institutional change were always accompanied by a shift in ideational power, for example, toward the Catholic Church in period 1, the modernist paradigm and corporatist arrangement in period 3 , and the various nonagricultural actors (environment, health, welfare, food) in period 5. Ideational power has also a strong influence on the ability of institutional innovations to move from isolated incubator examples to influencing broader system change (Geels 2004).

To summarize, the application of our framework to the pig sector shows that, in the long run, resilience depends on a variety of institutions that connect information, material, and financial flows in a well-aligned way. It also suggests that a combination of perturbations, institutional layering, and shifts in ideational power is an important institutional mechanism for resilience in general and transformability in particular. The emergence of small-scale transformative change in a variety of reconnected niches, as identified in stage 5 , might indicate a model for a broader reconnect as described by Termeer et al. (2017). This also links to the concept of bricolage, the rearrangement or recombination of institutional principles and practices in new and creative ways (Campbell 2004), and to the importance of strategic alliances between traditional and non-traditional actors as part of transformation (van Zwanenberg et al. 2018).

\section{CONCLUSIONS}

Disconnects between farming and urban systems are perceived to be an important cause of decreased resilience of BBPSs. We aimed to analyze how institutions influence resilience in complex BBPSs through shaping connects and disconnects? For this purpose, it integrated elements from institutional and resilience theory into a new framework. This framework includes relationships between four key concepts: perturbations; institutions, including structural or ideational power; connects and disconnects organized through material, financial, and informational flows; and resilience along the dimensions of robustness, adaptability, and transformability. This framework is applied to the historical case of pig livestock intensification in the Netherlands from 1870 to 2017.

Using the framework, we identified key junctures of perturbations as triggers for system reorganization. The institutions that developed in response to perturbations in turn shaped connects and disconnects, but these effects were dynamic and changed over time. Understanding these patterns can be useful for understanding the broader resilience dynamics of farming systems, and of BBPSs more broadly. If a BBPS is undergoing a period of perturbations, a focus on strengthening existing institutions may enhance robustness, whereas transformation is best enabled by institutions that allow more space for experimentation and innovation.

Our findings could enrich current debates on reconnecting urban and farming systems, in which a focus on the relocalization (e.g., Eakin et al. 2017) and the certification (e.g., Cashore 2002) paradigm seems to dominate. Although local institutions operate at the same temporal and spatial scale as the feedback signals, they do not fully address the diversity of interdependencies in BBPSs and therefore fail to effectively reconnect farming and urban systems (see also Sundkvist et al. 2005, Lamine 2015). Voluntary certification schemes may disclose information but are only successful if linked to material and financial flows, or even to regulation. Institutional complexity in terms of layering, 
redundancy, and bricolage is crucial for resilience, in particular in times of major perturbation. This is coherent with Ostrom's ideas about overcoming scale mismatches by building arrangements from the lowest level up to the entire interconnected system (Ostrom 1999). Consequently, building resilient BBPSs requires a variety of reconnecting institutions that involve local food networks, consumer-supported agriculture, urban farming, and locally sourced school food, as well as global roundtables, certifications schemes, trade policies, regulations, and so forth. This calls for refraining from a focus on local reconnects or certification only and for a tolerance of institutional complexity.

Despite its usefulness, the framework also has some weaknesses. The first relates to our main conclusion of dynamics and complexity. It is very difficult to describe all these dynamics and underlying mechanisms in a medium that is itself static. A possible next step in this research is to investigate these dynamics and mechanisms by "growing" them in a miniature version of the system. This is in fact inherent in the method of generative social science (Epstein 2006). A technique for doing this is agent-based modeling (Gilbert 2008), including modeling social dynamics (Hofstede 2019). An agent-based model is thus a living hypothesis about the system under study. Agent based modeling of the essential dynamics of the system allows to run the system thousands of times with different parameter settings that mimic different hypotheses or different scenarios. This in turn allows to explain the various relations and test hypotheses about how the identified mechanisms relate to resilience. A model of the case that focuses on spatial relationships and includes institutions is currently being developed.

The second weakness is the issue of boundaries. Although we tried to define the boundaries of the case study in terms of a specific farming system (pig husbandry) in a specific region (southern Netherlands) and took linkages with metropolitan consuming areas or fodder producing regions into account, we were not able to fully address externalities. Further research, in particular studies that analyze new reconnecting arrangements, should include these externalities. Otherwise, reconnects and increased resilience at the local level might result in loss of resilience far away. Here too, agent-based modeling might contribute.

Responses to this article can be read online at: http://www.ecologyandsociety.org/issues/responses. php/11206

\section{Acknowledgments:}

The research was supported by the strategic investment fund of Wageningen University and Research

\section{LITERATURE CITED}

Anderies, J. M., C. Folke, B. Walker, and E. Ostrom. 2013. Aligning key concepts for global change policy: robustness, resilience, and sustainability. Ecology and Society 18(2):8. http:// dx.doi.org/10.5751/ES-05178-180208
Arts, B. 2006. Forests, institutions, discourses: a discursiveinstitutional analysis of global forest politics. Inaugural address. Wageningen University \& Research, Wageningen, The Netherlands.

Bachrach, P., and M. S. Baratz. 1962. Two faces of power. American Political Science Review 56:947-952. https://doi. org/10.2307/1952796

Bekke, H., G. Neelen, and J de Vries. 1994. De salto mortale van het ministerie van Landbouw, Natuurbeheer en Visserij; beleid, organisatie en management op een breukvlak. Samsom H. D. Tjeenk Willink, Alphen aan den Rijn, The Netherlands.

Bieleman, J. 2010. Five centuries of farming: a short history of Dutch agriculture 1500-2000. Wageningen Academic, Wageningen, The Netherlands. https://doi.org/10.3920/978-90-8686-693-9

Biesbroek, R., J. Dupuis, and A. Wellstead. 2017. Explaining through causal mechanisms: resilience and governance of socialecological systems. Current Opinion in Environmental Sustainability 28:64-70. https://doi.org/10.1016/j.cosust.2017.08.007

Bijman, J. 2018. Exploring the sustainability of the cooperative model in dairy: the case of the Netherlands. Sustainability 10 (7):2498. https://doi.org/10.3390/su10072498

Bijman, J., K. J. Poppe, M. L. Cook, and C. Iliopoulos. 2012. Support for farmers' cooperatives - case study report Cebeco. Wageningen, The Netherlands. [online] URL: http://edepot.wur. n1/245000

Breeman, G. 2006. Cultivating trust. Dissertation. Leiden University, Leiden, The Netherlands.

Bues, A., and I. Theesfeld. 2012. Water grabbing and the role of power: shifting water governance in the light of agricultural investment. Water Alternatives 5(2):266-283.

Campbell, J. L. 2004. Institutional change and globalization. Princeton University Press, Princeton, New Jersey, USA.

Carpenter, S., B. Walker, J. M. Anderies, and N. Abel. 2001. From metaphor to measurement: resilience of what to what? Ecosystems 4(8):765-781. http://dx.doi.org/10.1007/s10021-001-0045-9

Carstensen, M. B., and V. A. Schmidt. 2016. Power through, over and in ideas: conceptualizing ideational power in discursive institutionalism. Journal of European Public Policy 23(3):318-337. https://doi.org/10.1080/13501763.2015.1115534

Cashore, B. 2002. Legitimacy and privatization of environmental governance: how non-state market-driven (NSMD) governance systems gain rule-making authority. Governance: An International Journal of Policy, Administration, and Institutions 15(4):503-529. https://doi.org/10.1111/1468-0491.00199

Cosens, B., L. Gunderson, C. Allen, and M. H. Benson. 2014. Identifying legal, ecological and governance obstacles, and opportunities for adapting to climate change. Sustainability 6 (4):2338-2356. https://doi.org/10.3390/su6042338

Cretella, A., and M. S. Buenger. 2016. Food as creative city politics in the city of Rotterdam. Cities 51:1-10. https://doi.org/10.1016/ j.cities.2015.12.001 
Cumming, G. S., A. Buerkert, E. M. Hoffmann, E. Schlecht, S. von Cramon-Taubadel, and T. Tscharntke. 2014. Implications of agricultural transitions and urbanization for ecosystem services. Nature 515(7525):50-57. https://doi.org/10.1038/nature13945

Daugbjerg, C., and P. H. Feindt. 2017. Post-exceptionalism in public policy: transforming food and agricultural policy. Journal of European Public Policy 24(11):1565-1584. https://doi. org/10.1080/13501763.2017.1334081

Davidson, D. J. 2010. The applicability of the concept of resilience to social systems: some sources of optimism and nagging doubts. Society and Natural Resources 23:1135-1149. https://doi. org/10.1080/08941921003652940

Duit, A., P. H. Feindt, and J. Meadowcroft. 2015. Greening Leviathan: the rise of the environmental state? Environmental Politics 25(1):1-23. https://doi.org/10.1080/09644016.2015.1085218

Eakin, H., X. Rueda, and A. Mahanti. 2017. Transforming governance in telecoupled food systems. Ecology and Society 22 (4):32. https://doi.org/10.5751/ES-09831-220432

Eakin, H., A. Winkels, and J. Sendzimir. 2009. Nested vulnerability: exploring cross-scale linkages and vulnerability teleconnections in Mexican and Vietnamese coffee systems. Environmental Science \& Policy 12(4):398-412. https://doi. org/10.1016/j.envsci.2008.09.003

Epstein, J. M. 2006. Generative social science: studies in agentbased computational modeling. Princeton University Press, Princeton, New Jersey, USA. https://doi.org/10.1515/9781400842872

Feindt, P. H. 2018. EU agricultural policy. Pages 115-133 in $\mathrm{H}$. Heineltand S. Münch, editors. Handbook of European policies: interpretive approaches to the EU. Edward Elgar, London, UK. https://doi.org/10.4337/9781784719364.00014

Feindt, P. H., and A. Flynn. 2009. Policy stretching and institutional layering: British food policy between security, safety, quality, health and climate change. British Politics 4(3):386-414. https://doi.org/10.1057/bp.2009.13

Folke, C., S. R. Carpenter, B. Walker, M. Scheffer, T. Chapin, and J. Rockström. 2010. Resilience thinking: integrating resilience, adaptability and transformability. Ecology and Society 15(4):20. https://doi.org/10.5751/ES-03610-150420

Fresco, L. O., and K. J. Poppe. 2016. Towards a common agricultural and food policy. Wageningen University, The Netherlands. https://doi.org/10.18174/390280

Frouws, J. 1994. Mest en macht. Dissertation. Wageningen University, The Netherlands.

Ge, L., N. P. R. Anten, I. D. E. Dixhoorn, P. H. Feindt, K. Kramer, R. Leemans, M. P. M. Meuwissen, H. Spoolder, and W. Sukkel. 2016. Why we need resilience thinking to meet societal challenges in bio-based production systems. Current Opinion in Environmental Sustainability 23:17-27. https://doi.org/10.1016/j. cosust.2016.11.009

Ge, L., and C. A. Brewster. 2016. Informational institutions in the agrifood sector: meta-information and meta-governance of environmental sustainability. Current Opinion in Environmental Sustainability 18:73-81. https://doi.org/10.1016/j.cosust.2015.10.002
Geels, F. W. 2004. From sectoral systems of innovation to sociotechnical systems: insights about dynamics and change from sociology and institutional theory. Research Policy 33 (6-7):897-920. https://doi.org/10.1016/j.respol.2004.01.015

Gilbert, N. 2008. Agent-based models. SAGE, Thousand Oaks, California, USA. https://doi.org/10.4135/9781412983259

Gupta, J., C. Termeer, J. Klostermann, S. Meijerink, M. van den Brink, P. Jong, S. Nooteboom, and E. Bergsma. 2010. The adaptive capacity wheel: a method to assess the inherent characteristics of institutions to enable the adaptive capacity of society. Environmental Science \& Policy 13(6):459-471. https://doi. org/10.1016/j.envsci.2010.05.006

Hay, C. 2002. Political analysis: a critical introduction. Palgrave MacMillan, Basingstoke, UK. https://doi.org/10.1007/978-0-230-62911-0

Health Council. 2012. Health risks associated with livestock farms. Publication no. 2012/27E. Health Council of the Netherlands, Den Haag, The Netherlands. [online] URL: https://www. healthcouncil.n1/documents/advisory-reports/2012/11/30/healthrisks-associated-with-livestock-farms

Hofstede, G. J. 2019. GRASP agents: social first, intelligent later. AI \& Society 34(3):535-543. https://doi.org/10.1007/s00146-017-0783-7

Holling, C. S., and L. H. Gunderson. 2002. Resilience and adaptive cycles. Pages 25-62 in L. H. Gunderson and C. S. Holling, editors. Panarchy: understanding transformations in human and natural systems. Island Press, Washington, D.C., USA.

Hull, V., M.-N. Tuanmu, and J. Liu. 2015. Synthesis of humannature feedbacks. Ecology and Society 20(3):17. http://dx.doi. org/10.5751/ES-07404-200317

Lamine, C. 2015. Sustainability and resilience in agrifood systems: reconnecting agriculture, food and the environment. Sociologia Ruralis 55(1):41-61. https://doi.org/10.1111/soru.12061

Lukes, S. 1974. Power: a radical view. Macmillan, New York, New York, USA.

March, J. G., and J. P. Olsen. 1989. Rediscovering institutions. The organizational basis of politics. Free Press, New York, New York, USA.

McKinnon, I., P. T. Hurley, C. C. Myles, M. Maccaroni, and T. Filan. 2019. Uneven urban metabolisms: toward an integrative (ex)urban political ecology of sustainability in and around the city. Urban Geography 40(3):352-377. https://doi. org/10.1080/02723638.2017.1388733

Meuwissen, M. P. M., P. H. Feindt, A. Spiegel, C. J. A. M. Termeer, E. Mathijs, Y. de Mey, R. Finger, A. Balmann, E. Wauters, J. Urquhart, et al. 2019. A framework to assess the resilience of farming systems. Agricultural Systems 176:102656. https://doi. org/10.1016/j.agsy.2019.102656

Meuwissen, M. P. M., S. H. Horst, R. B. M. Huirne, and A. A. Dijkhuizen. 1999. A model to estimate the financial consequences of classical swine fever outbreaks: principles and outcomes. Preventive Veterinary Medicine 42(3-4):249-270. https://doi. org/10.1016/S0167-5877(99)00079-3

Moulier-Boutang, Y. 2011. Cognitive capitalism. Polity Press, Cambridge, UK. 
Newman, K. L. 2000. Organizational transformation during institutional upheaval. Academy of Management Review 25 (3):602-619. https://doi.org/10.5465/amr.2000.3363525

North, D. C. 1991. Institutions. Journal of Economic Perspectives 5:97-112. https://doi.org/10.1257/jep.5.1.97

Olsson, P., L. H. Gunderson, S. R. Carpenter, P. Ryan, L. Lebel, C. Folke, and C. S. Holling. 2006. Shooting the rapids: navigating transitions to adaptive governance of social-ecological systems. Ecology and Society 11(1):18. https://doi.org/10.5751/ES-01595-110118

Ostrom, E. 1999. Coping with tragedies of the commons. Annual Review of Political Science 2:493-535. https://doi.org/10.1146/ annurev.polisci.2.1.493

Ostrom, E. 2008. Institutions and the environment. Economic Affairs 28(3):24-31. https://doi.org/10.1111/j.1468-0270.2008.00840. $\underline{\mathrm{x}}$

Ostrom, E. 2009. A general framework for analyzing sustainability of social-ecological systems. Science 325 (5939):419-422. https://doi.org/10.1126/science.1172133

Pierson, P. 2004. Politics in time: history, institutions, and social analysis. Princeton University Press, Princeton, New Jersey, USA. https://doi.org/10.1515/9781400841080

Qviström, M. 2007. Landscapes out of order: studying the inner urban fringe beyond the rural-urban divide. Geografiska Annaler: Series B, Human Geography 89(3):269-282. https://doi. org/10.1111/j.1468-0467.2007.00253.X

Reyers, B., C. Folke, M.-L. Moore, R. Biggs, and V. Galaz. 2018. Social-ecological systems insights for navigating the dynamics of the Anthropocene. Annual Review of Environment and Resources 43:267-289. https://doi.org/10.1146/annurev-environ-110615-085349

Rosenthal, U., M. T. Charles, and P. 't Hart, editors. 1989. Coping with crises: the management of disasters, riots and terrorism. Charles C. Thomas, Springfield, Illinois, USA.

Sage, C. 2013. The interconnected challenges for food security from a food regimes perspective: energy, climate and malconsumption. Journal of Rural Studies 29:71-80. https://doi. org/10.1016/j.jrurstud.2012.02.005

Sonnino, R., C. L. Torres, and S. Schneider. 2014. Reflexive governance for food security: the example of school feeding in Brazil. Journal of Rural Studies 36:1-12. https://doi.org/10.1016/ j.jrurstud.2014.06.003

Steffen, W., P. J. Crutzen, and J. R. McNeill. 2007. The Anthropocene: Are humans now overwhelming the great forces of nature? AMBIO 36(8):614-621. https://doi.org/10.1579/0044-7447 (2007)36[614:TAAHNO]2.0.CO;2

Sundkvist, A., R. Milestad, and A. Jansson. 2005. On the importance of tightening feedback loops for sustainable development of food systems. Food Policy 30(2):224-239. https:// doi.org/10.1016/j.foodpol.2005.02.003

Termeer, C. J. A. M. 1993. Dynamiek en inertie rondom mestbeleid; een studie naar veranderingsprocessen in het varkenshouderijnetwerk. Vuga, The Hague, The Netherlands.
Termeer, C. J. A. M., H. Dagevos, G. Breeman, and A.-C. Hoes. 2016. Maatschappelijk vertrouwen in de varkenshouderij. Deel 1 Managementsamenvatting en conclusies. Wageningen, The Netherlands. [online] URL: http://edepot.wur.n1/279565

Termeer, C. J. A. M., A. Dewulf, and G. R. Biesbroek. 2017. Transformational change: governance interventions for climate change adaptation from a continuous change perspective. Journal of Environmental Planning and Management 60(4):558-576. https://doi.org/10.1080/09640568.2016.1168288

Termeer, C. J. A. M., M. Stuiver, A. Gerritsen, and P. Huntjens. 2013. Integrating self-governance in heavily regulated policy fields: insights from a Dutch farmers' cooperative. Journal of Environmental Policy and Planning 15(2):285-302. https://doi. org/10.1080/1523908X.2013.778670

Termeer, C. J. A. M., and R. A. Werkman. 2011. Changing closed agricultural policy communities. Critical Policy Studies 5 (3):283-298. https://doi.org/10.1080/19460171.2011.606301

Thelen, K. 1999. Historical institutionalism in comparative politics. Annual Review of Political Science 2:369-404. https://doi. org/10.1146/annurev.polisci.2.1.369

Urruty, N., D. Tailliez-Lefebvre, and C. Huyghe. 2016. Stability, robustness, vulnerability and resilience of agricultural systems. A review. Agronomy for Sustainable Development 36:15. https://doi. org/10.1007/s13593-015-0347-5

Van der Heijden, A., and J. M. Cramer. 2017. Change agents and sustainable supply chain collaboration: a longitudinal study in the Dutch pig farming sector from a sensemaking perspective. Journal of Cleaner Production 166:967-987. https://doi. org/10.1016/j.jclepro.2017.08.074

van Lieshout, M., A. Dewulf, N. Aarts, and C. Termeer. 2013. Framing scale increase in Dutch agricultural policy 1950-2012. NJAS Wageningen Journal of Life Sciences 64-65:35-46. https:// doi.org/10.1016/j.njas.2013.02.001

Van Zanden, J. L. 1994. The transformation of European agriculture in the 19th century: the case of The Netherlands. VU University Press, Amsterdam, The Netherlands.

Van Zwanenberg, P., A. Cremaschi, M. Obaya, A. Marin, and V. Lowenstein. 2018. Seeking unconventional alliances and bridging innovations in spaces for transformative change: the seed sector and agricultural sustainability in Argentina. Ecology and Society 23(3):11. https://doi.org/10.5751/ES-10033-230311

Vatn, A. 2005. Rationality, institutions and environmental policy. Ecological Economics 55(2):203-217. https://doi.org/10.1016/j. ecolecon.2004.12.001

Vij, S., V. Narain, T. Karpouzoglou, and P. Mishra. 2018. From the core to the periphery: conflicts and cooperation over land and water in periurban Gurgaon, India. Land Use Policy 76:382-390. https://doi.org/10.1016/j.landusepol.2018.04.050

Walker, B., C. S. Holling, S. R. Carpenter, and A. Kinzig. 2004. Resilience, adaptability and transformability in social-ecological systems. Ecology and Society 9(2):5. https://doi.org/10.5751/ ES-00650-090205 
Westley, F., P. Olsson, C. Folke, T. Homer-Dixon, H. Vredenburg, D. Loorbach, J. Thompson, M. Nilsson, E. Lambin, J. Sendzimir, B. Banerjee, V. Galaz, and S. van der Leeuw. 2011. Tipping toward sustainability: emerging pathways of transformation. AMBIO 40 (7):762-780. https://doi.org/10.1007/s13280-011-0186-9

Williamson, O. E. 2000. The new institutional economics: taking stock, looking ahead. Journal of Economic Literature 38 (3):595-613. https://doi.org/10.1257/jel.38.3.595

Wiskerke, J. S. C., B. B. Bock, M. Stuiver, and H. Renting. 2003. Environmental co-operatives as a new mode of rural governance. NJAS Wageningen Journal of Life Sciences 51(1-2):9-25. https:// doi.org/10.1016/s1573-5214(03)80024-6

Zhang, W., T. H. Ricketts, C. Kremen, K. Carney, and S. M. Swinton. 2007. Ecosystem services and dis-services to agriculture. Ecological Economics 64(2):253-260. https://doi.org/10.1016/j. ecolecon.2007.02.024

Zoomers, A., F. van Noorloos, K. Otsuki, G. Steel, and G. van Westen. 2017. The rush for land in an urbanizing world: from land grabbing toward developing safe, resilient, and sustainable cities and landscapes. World Development 92:242-252. https://doi. org/10.1016/j.worlddev.2016.11.016 